\title{
VALIDITY OF THE ENDOGENOUS CREATININE CLEARANCE AS A MEASURE OF GLOMERULAR FILTRATION RATE IN THE DISEASED HUMAN KIDNEY ${ }^{\mathbf{1 ,} 2}$
}

\author{
By BENJAMIN F. MILLER,3 ALEXANDER LEAF,4 AUDLEY R. MAMBY, AND \\ ZELMA MILLER ${ }^{5}$
}

\begin{abstract}
(From the Children's Medical Service and the Department of Medicine, the Massachusetts General Hospital, and the Harvard Medical School, Boston, Massachusetts)
\end{abstract}

(Submitted for publication September 17, 1951 ; accepted January 8, 1952)

\section{INTRODUCTION}

Twenty-five years ago Rehberg proposed the exogenous creatinine clearance for the measurement of glomerular filtration rate (1). In the $d o g$ and rabbit, this clearance provides a simple and accurate method of determining the filtration rate, coinciding with the inulin and ferrocyanide clearances $(2,3)$. Subsequently, Shannon (4) and Miller and Winkler (5) found in man that the exogenous creatinine clearance was considerably higher than the glomerular filtration rate. ${ }^{6}$ Despite the fact that the compound he chose did not provide an exact measure of the glomerular clearance in man, Rehberg's pioneering development opened a whole new area of research in renal dynamics. Unfortunately, the unreliability of $e x-$ ogenous creatinine and ferrocyanide (7) clearances in man left only inulin for the measurement of filtration rate in the human kidney.

The determination of inulin clearance has several serious disadvantages. It was inevitable, therefore, that the search for simpler methods of measuring glomerular filtration rate in man would continue. It occurred to one of us some years ago that the endogenous creatinine clearance might prove to be a true measure of the filtration rate.

1 Aided by grants from the Research Corporation, New York City, and the Bristol-Myers Company, New York City.

2 A preliminary report of this work appeared in the Proceedings of the Forty-Third Annual Meeting of the American Society for Clinical Investigation, J. Clin. Invest., $1951,30,661$.

8 Present address : Peter Bent Brigham Hospital, Boston, Massachusetts.

- National Research Council Fellow in the Medical Sciences, 1949-1951.

- Present address: Children's Cancer Research Foundation, Children's Medical Center, Boston, Massachusetts.

- The inulin clearance value is regarded as equivalent to the glomerular filtration rate in $\operatorname{man}(2,6)$.
Miller and Dubos developed a specific enzymatic method for the estimation of creatinine $(8,9)$, and this method was employed by Miller and Winkler to measure the clearance of specific endogenous creatinine in normal and pathological states (5). They demonstrated that in normal individuals the specific endogenous creatinine clearance lay below the level of Rehberg's exogenous clearance. In some instances, it equalled the inulin clearance. In addition, these authors found that the specific endogenous creatinine clearance was consistently higher than the inulin clearance in patients with diminished renal function, as in chronic glomerulonephritis. Further studies by Taggart, Alving and Miller $(10,11)$, employing a more sensitive colorimeter, showed that the specific endogenous creatinine clearance in both normal and hypertensive subjects was almost always somewhat higher than the inulin clearance.

Other workers, using non-specific methods for analysis, have claimed that the endogenous creatinine chromogen clearance may be employed as a measure of glomerular filtration rate in man. These results have been summarized by Smith (2).

Brod and Sirota reported a high degree of correspondence between endogenous-creatinine-chromogen and inulin clearances in normal subjects and patients with renal disease (12). Because of the simplicity of the endogenous creatinine clearance, there has been a tendency for many investigators to substitute this clearance for the inulin clearance. In view of the discrepancy between the results of Miller and Winkler (5) and Taggart, Alving and Miller $(10,11)$, and those obtained by Brod and Sirota on the validity of the creatinine clearance, it seemed important to extend these studies. We have therefore determined both the specific creatinine clearance as described by Miller and Winkler and the non-specific creatinine chromogen 
clearance, used by Brod and Sirota. For the most part, our subjects were patients who presented evidence of considerable renal derangement, either organic as a result of chronic inflammatory disease, or functional, from cardiac failure. We have purposely selected patients with considerable renal pathology since we feel that general acceptability of any glomerular clearance measurement depends on its equivalence with the clearance of inulin in this type of patient.

\section{METHODS}

The clearances of specific endogenous creatinine, total creatinine chromogen and inulin were determined on nine patients. Prior to the collection of samples, these patients had received 5 grams of allantoin by mouth. ${ }^{7}$ We have no reason to suspect that allantoin modifies either the inulin or creatinine clearance.

The inulin clearance was obtained by the method described by Goldring and Chasis (14) which employs a priming dose of inulin ${ }^{8}$ and a continuous intravenous infusion to ensure a constant blood level.

Blood samples were centrifuged as soon as they had clotted, and the serum was withdrawn. Sera and urines were stored in the frozen state if they were not analyzed immediately. All analyses were performed in duplicate.

\section{Inulin}

Inulin was determined by the Rolf, Surtshin and White (15) modification of the Alving, Rubin and Miller diphenyl amine method (16). Sera were yeasted according to the method of Alving, Rubin and Miller only in experiments where inulin had been administered in a 2 per cent glucose solution to the patients with congestive heart failure.

Blood sera were deproteinized by acid cadmium sulfate (17), as were urines which contained protein. Aliquots of blood filtrates and diluted urines, containing approximately 20 micrograms of inulin in $2 \mathrm{cc}$, , were analyzed in duplicate along with 20 microgram standards, freshly prepared from a stock solution containing $1 \mathrm{mg}$. per cc.

A blood sample drawn prior to the administration of inulin served to correct for glucose in subsequent blood samples. A control urine sample was also collected just before the priming dose of inulin. This gave a measure of non-inulin reducing substance in urine, and was used to correct the values obtained on urines collected during the clearance periods. Generally, the control urines contributed very little color. However, in urine from uremic patients, the correction is considerably greater, as has been observed by other investigators (12).

${ }^{7}$ Allantoin was administered to obtain the allantoin clearances reported in the accompanying paper (13).

$8 \mathrm{We}$ are indebted to the U. S. Standard Products Company, Woodworth, Wisconsin, for a generous supply of inulin.

\section{Creatinine}

Both total creatinine chromogen (apparent creatinine) and non-creatinine chromogen (the chromogen remaining after treatment with the Miller-Dubos enzyme) were determined by the Bonsnes and Taussky (18) modification of the Jaffe reaction. Serum proteins were precipitated by the addition of $8 \mathrm{cc}$. of water, $0.5 \mathrm{cc}$. 10 per cent sodium tungstate and $0.5 \mathrm{cc}$. $2 / 3 \mathrm{~N} \mathrm{H}_{2} \mathrm{SO}_{4}$ to $1 \mathrm{cc}$. of serum in the usual manner. Urine samples which contained protein were also precipitated with tungstate-sulfuric acid (5 cc. of urine plus $1 \mathrm{cc}$. of 10 per cent sodium tungstate and 1 cc. of $2 / 3 \mathrm{~N} \mathrm{H}_{2} \mathrm{SO}_{4}$ ). To 6 cc. of serum filtrate or appropriately diluted urine, $2 \mathrm{cc}$. of $0.04 \mathrm{M}$ picric acid were added. The tubes were placed in a $28^{\circ} \mathrm{C}$. water bath, and 2 cc. of $0.75 \mathrm{~N} \mathrm{NaOH}$ were added at carefully timed intervals. The color formed was read in an Evelyn colorimeter ${ }^{*}$ with filter 520 after exactly 15 minutes, and the total creatinine chromogen was determined by reference to a standard curve.

For the determination of specific creatinine, $6 \mathrm{cc}$. of blood filtrate or diluted urine were incubated with $1 \mathrm{cc}$. of water, $0.5 \mathrm{cc}$. molar phosphate buffer, $\mathrm{pH} 7.0$, and 0.5 cc. of bacterial suspension (19) in an unstoppered Erlenmeyer flask for 1 hour at $37^{\circ} \mathrm{C}$. The contents of the flask were centrifuged at high speed for 15 minutes, and the residual chromogen (non-creatinine chromogen) was determined on $6 \mathrm{cc}$. of the supernatant fluid, exactly as described above. The difference between total creatinine chromogen and non-creatinine chromogen represents specific creatinine.

\section{RESULTS}

Table I summarizes the clearances obtained in nine patients. The ratio of total creatinine chromogen clearance to inulin clearance permits comparison with the results of Brod and Sirota (12) who employed this measure of "creatinine." Also, the ratios of specific creatinine clearance to inulin clearance are reported.

\section{Total creatinine chromogen clearance}

The ratios of total creatinine chromogen clearance to inulin clearance fell within 10 per cent of unity in only five of 28 clearance periods. The remainder ranged from 0.56 to 1.64 . Two of our three patients with rheumatic heart disease and cardiac failure exhibited the very low total creatinine chromogen to inulin clearance ratios reported by Baldwin, Sirota and Villarreal (20) in cardiac decompensation. In patient B. M., the ratios of $0.58,0.56$, and 0.63 are remarkably low.

\section{Specific creatinine clearance}

These clearances show the same trend as the non-specific ones. In all but one case, they have 
TABLE I

Comparison of inulin and endogenous creatinine clearances

\begin{tabular}{|c|c|c|c|c|c|c|c|c|c|c|c|c|c|}
\hline \multirow{2}{*}{ Patient } & \multirow{2}{*}{ Sex } & \multirow{2}{*}{ Age } & \multirow{2}{*}{ Diagnosis } & \multirow{2}{*}{ Period } & \multirow{2}{*}{$\begin{array}{l}\text { Urine } \\
\text { flow } \\
(c c . / \\
\min .)\end{array}$} & \multicolumn{2}{|c|}{ Inulin } & \multicolumn{2}{|c|}{$\begin{array}{l}\text { Creatinine } \\
\text { chromogen }\end{array}$} & \multicolumn{2}{|c|}{ Specific creatinine } & \multicolumn{2}{|c|}{ Clearance ratios } \\
\hline & & & & & & $\begin{array}{c}\text { Serum } \\
\text { conc'n } \\
(m g . / \\
100 \mathrm{cc} .)\end{array}$ & $\mid \begin{array}{c}\text { Clear- } \\
\text { ance* } \\
(c c . / \min .)\end{array}$ & $\left|\begin{array}{c}\text { Serum } \\
\text { conc'n } \\
(m g . / \\
100 \text { cc. })\end{array}\right|$ & $\begin{array}{c}\text { Clear- } \\
\text { ance } \\
(\text { cc./min. })\end{array}$ & \begin{tabular}{|c|} 
Serum \\
conc'n \\
$(m g . /$ \\
100 cc. $)$
\end{tabular} & $\begin{array}{c}\text { Clear- } \\
\text { ance } \\
(c c . / m i n .)\end{array}$ & $\begin{array}{c}\text { Creatinine } \\
\text { chromogen / } \\
\text { inulin }\end{array}$ & $\begin{array}{c}\text { Specific } \\
\text { creatinine/ } \\
\text { inulin }\end{array}$ \\
\hline S. A. S. & $\mathbf{M}$ & 49 & $\begin{array}{l}\text { Hyperparathyroid- } \\
\text { ism with nephro- } \\
\text { calcinosis }\end{array}$ & $\begin{array}{l}1 \\
2 \\
3\end{array}$ & $\begin{array}{l}3.3 \\
3.1 \\
3.5\end{array}$ & $\begin{array}{l}12.4 \\
14.0 \\
14.7\end{array}$ & $\begin{array}{l}11.9 \\
10.5 \\
11.6\end{array}$ & $\begin{array}{l}4.02 \\
4.02 \\
4.00\end{array}$ & $\begin{array}{l}19.2 \\
17.2 \\
17.5\end{array}$ & $\begin{array}{l}3.81 \\
3.80 \\
3.78\end{array}$ & $\begin{array}{l}20.3 \\
18.2 \\
18.5\end{array}$ & $\begin{array}{l}1.61 \\
1.64 \\
1.51\end{array}$ & $\begin{array}{l}1.71 \\
1.73 \\
1.59\end{array}$ \\
\hline M. W. & $F$ & 23 & $\begin{array}{l}\text { Lupus erythemato- } \\
\text { sus with severe } \\
\text { hypertension }\end{array}$ & $\begin{array}{l}1 \\
2 \\
3\end{array}$ & $\begin{array}{l}3.2 \\
2.9 \\
3.4\end{array}$ & $\begin{array}{l}19.6 \\
21.4 \\
23.8\end{array}$ & $\begin{array}{l}22.3 \\
21.0 \\
22.2\end{array}$ & $\begin{array}{l}3.24 \\
3.24 \\
3.25\end{array}$ & $\begin{array}{l}28.2 \\
26.1 \\
27.7\end{array}$ & $\begin{array}{l}2.78 \\
2.82 \\
2.78\end{array}$ & $\begin{array}{l}30.6 \\
28.0 \\
31.3\end{array}$ & $\begin{array}{l}1.27 \\
1.24 \\
1.25\end{array}$ & $\begin{array}{l}1.37 \\
1.33 \\
1.41\end{array}$ \\
\hline R. P. & $\mathbf{M}$ & 35 & $\begin{array}{l}\text { Diabetes with inter- } \\
\text { capillary glomeru- } \\
\text { lar sclerosis }\end{array}$ & $\begin{array}{l}1 \\
2 \\
3 \\
4\end{array}$ & $\begin{array}{l}5.2 \\
6.5 \\
7.7 \\
8.1\end{array}$ & $\begin{array}{l}23.5 \\
23.6 \\
23.7 \\
23.0\end{array}$ & $\begin{array}{l}53.0 \\
54.4 \\
58.2 \\
58.6\end{array}$ & $\begin{array}{l}1.57 \\
1.54 \\
1.56 \\
1.48\end{array}$ & $\begin{array}{l}65.9 \\
66.5 \\
65.1 \\
64.7\end{array}$ & $\begin{array}{l}1.20 \\
1.13 \\
1.14 \\
1.13\end{array}$ & $\begin{array}{l}74.8 \\
76.9 \\
74.6 \\
77.6\end{array}$ & $\begin{array}{l}1.24 \\
1.22 \\
1.12 \\
1.10\end{array}$ & $\begin{array}{l}1.41 \\
1.41 \\
1.28 \\
1.33\end{array}$ \\
\hline A. $\mathrm{M}$. & M & 52 & $\begin{array}{l}\text { Chronic glomerular } \\
\text { nephritis with ne- } \\
\text { phrosis }\end{array}$ & $\begin{array}{l}1 \\
2 \\
3\end{array}$ & $\begin{array}{l}1.2 \\
1.5 \\
1.1\end{array}$ & $\begin{array}{l}39.5 \\
43.6 \\
48.4\end{array}$ & $\begin{array}{l}56.6 \\
56.2 \\
55.1\end{array}$ & $\begin{array}{l}1.38 \\
1.37 \\
1.31\end{array}$ & $\begin{array}{l}81.5 \\
77.5 \\
83.6\end{array}$ & $\begin{array}{l}1.19 \\
1.18 \\
1.12\end{array}$ & $\begin{array}{l}91.0 \\
86.8 \\
94.9\end{array}$ & $\begin{array}{l}1.43 \\
1.38 \\
1.52\end{array}$ & $\begin{array}{l}1.60 \\
1.54 \\
1.72\end{array}$ \\
\hline A. J. & F & 26 & $\begin{array}{l}\text { Anterior and post- } \\
\text { pituitary deficiency }\end{array}$ & $\begin{array}{l}1 \\
2 \\
3\end{array}$ & $\begin{array}{l}6.2 \\
5.7 \\
6.2\end{array}$ & $\begin{array}{l}49.1 \\
52.6 \\
57.2\end{array}$ & $\begin{array}{l}66.6 \\
58.1 \\
64.9\end{array}$ & $\begin{array}{l}0.88 \\
0.91 \\
0.92\end{array}$ & $\begin{array}{l}88.1 \\
70.1 \\
73.5\end{array}$ & $\begin{array}{l}0.66 \\
0.66 \\
0.65\end{array}$ & $\begin{array}{r}115.5 \\
94.6 \\
103.8\end{array}$ & $\begin{array}{l}1.32 \\
1.21 \\
1.13\end{array}$ & $\begin{array}{l}1.74 \\
1.63 \\
1.60\end{array}$ \\
\hline A. L. & $\mathbf{M}$ & 45 & $\begin{array}{l}\text { Rheumatic heart } \\
\text { disease }\end{array}$ & $\begin{array}{l}1 \\
2 \\
3\end{array}$ & $\begin{array}{l}0.6 \\
0.6 \\
0.6\end{array}$ & $\begin{array}{l}30.0 \\
28.6 \\
29.2\end{array}$ & $\begin{array}{l}78.6 \\
80.7 \\
82.5\end{array}$ & $\begin{array}{l}0.96 \\
0.91 \\
0.88\end{array}$ & $\begin{array}{l}\mathbf{5 0 . 6} \\
\mathbf{5 5 . 1} \\
\mathbf{5 5 . 0}\end{array}$ & $\begin{array}{l}0.70 \\
0.65 \\
0.62\end{array}$ & $\begin{array}{l}65.0 \\
72.3 \\
72.5\end{array}$ & $\begin{array}{l}0.64 \\
0.68 \\
0.67\end{array}$ & $\begin{array}{l}0.83 \\
0.90 \\
0.88\end{array}$ \\
\hline J. R. & $\mathbf{M}$ & 21 & $\begin{array}{l}\text { Vitamin D-resistant } \\
\text { rickets }\end{array}$ & $\begin{array}{l}1 \\
2 \\
3\end{array}$ & $\begin{array}{l}9.0 \\
8.1 \\
8.5\end{array}$ & $\begin{array}{l}51.4 \\
51.6 \\
51.8\end{array}$ & $\begin{array}{r}101.5 \\
88.5 \\
86.4\end{array}$ & $\begin{array}{l}0.99 \\
0.99 \\
0.97\end{array}$ & $\begin{array}{r}105.0 \\
94.6 \\
92.9\end{array}$ & $\begin{array}{l}0.99 \\
0.94 \\
0.97\end{array}$ & $\begin{array}{r}105.0 \\
94.6 \\
92.9\end{array}$ & $\begin{array}{l}1.03 \\
1.07 \\
1.07\end{array}$ & $\begin{array}{l}1.03 \\
1.07 \\
1.07\end{array}$ \\
\hline F. B. & $\mathrm{F}$ & 39 & $\begin{array}{l}\text { Rheumatic heart } \\
\text { disease }\end{array}$ & $\begin{array}{l}1 \\
2 \\
3\end{array}$ & $\begin{array}{l}8.1 \\
8.4 \\
7.5\end{array}$ & $\begin{array}{l}30.4 \\
30.1 \\
29.7\end{array}$ & $\begin{array}{r}103.8 \\
88.0 \\
86.1\end{array}$ & $\begin{array}{l}0.83 \\
0.84 \\
0.89\end{array}$ & $\begin{array}{r}90.4 \\
77.1 \\
78.4\end{array}$ & $\begin{array}{l}0.51 \\
0.52 \\
0.57\end{array}$ & $\begin{array}{l}134.2 \\
116.6 \\
112.0\end{array}$ & $\begin{array}{l}0.87 \\
0.88 \\
0.91\end{array}$ & $\begin{array}{l}1.29 \\
1.33 \\
1.30\end{array}$ \\
\hline B. $\mathrm{M}$. & $\mathbf{F}$ & 31 & $\begin{array}{l}\text { Rheumatic heart } \\
\text { disease }\end{array}$ & $\begin{array}{l}1 \\
2 \\
3\end{array}$ & $\begin{array}{l}0.7 \\
0.8 \\
0.9\end{array}$ & $\begin{array}{l}22.6 \\
20.4 \\
21.4\end{array}$ & $\begin{array}{r}95.0 \\
109.5 \\
114.0\end{array}$ & $\begin{array}{l}0.72 \\
0.73 \\
0.69\end{array}$ & $\begin{array}{l}55.5 \\
61.1 \\
72.1\end{array}$ & $\begin{array}{l}0.46 \\
0.47 \\
0.43\end{array}$ & $\begin{array}{r}77.5 \\
91.1 \\
108.0\end{array}$ & $\begin{array}{l}0.58 \\
0.56 \\
0.63\end{array}$ & $\begin{array}{l}0.82 \\
0.83 \\
0.95\end{array}$ \\
\hline
\end{tabular}

* All clearances are corrected for body surface area of 1.73 sq. meters.

higher absolute values because the concentration of specific creatinine in serum is lower than that of total creatinine chromogen. The urinary creatinine values obtained by the two methods are essentially the same. The ratios of specific creatinine clearance to inulin clearance also deviate considerably from the required value of unity. The lowest specific creatinine/inulin ratio was 0.82 , and the highest, 1.74 .

\section{DISCUSSION}

The clearance values observed in these patients substantiate the conclusion reached by Miller and Winkler in 1938 that the endogenous creatinine clearance in subjects with depressed renal function is usually higher than the inulin clearance (5). In patient S. A. S., who showed the greatest reduction in function, the specific creatinine/inulin ratios averaged 1.68 and the total creatinine chromogen/ inulin ratios, 1.59. Similar results were obtained in patient A. M. whose kidney function was considerably better, but was still only 50 per cent of normal because of glomerular nephritis in the nephrotic stage. This patient was found to have specific creatinine/inulin ratios averaging 1.62 , and the corresponding creatinine chromogen/inulin value of 1.45 .

It is difficult to reconcile the data obtained in our present study or by Miller and Winkler (5) with the result reported by Brod and Sirota (12). These authors studied 13 adult patients with renal disease and found satisfactory correspondence be- 
tween the creatinine chromogen and inulin clearances except in one patient, whose chromogen/ inulin clearance ratio averaged 1.61 .

Brod and Sirota themselves have emphasized that in the infant, the endogenous creatinine chromogen clearance is not valid (12). Baldwin, Sirota, and Villarreal (20) have also pointed out that the endogenous creatinine chromogen clearance is substantially lower than the inulin clearance in patients with congestive heart failure and edema. Also, Brod (21) described a patient suffering from malignant hypertension associated with chronic pyelonephritis who showed some endogenous creatinine clearance values that were markedly lower than inulin. Brod and Kotátko (22) found in some patients with renal disease that the clearance of endogenous creatinine lay well above the inulin clearance. In these subjects, caronamide tended to bring the endogenous creatinine/inulin clearance ratio down to unity. The ratios mentioned by Brod and Koťátko are fully as high as those reported by us in the present communication and, previously, by Miller and Winkler (5). Also, the demonstration that caronamide reduces the endogenous creatinine clearance provides additional evidence that tubular excretion of endogenous creatinine occurred in these patients. Similar observations in chronic renal insufficiency have been made by Hare and associates (23).

It is clear that both Brod and Sirota question the validity of their endogenous creatinine chromogen clearance as a measure of the filtration rate in (a) normal infants, (b) patients with congestive heart failure, and (c) some patients with renal disease. We feel that such numerous exceptions would make the endogenous creatinine chromogen clearance unreliable in any studies which demand a relatively high degree of accuracy. If one wishes only a practical test of renal function, it is questionable whether anything is gained by using the non-specific, endogenous creatinine chromogen clearance in place of the urea clearance.

Our results hold no greater hope for the use of the specific endogenous creatinine clearance as a precise measure of the filtration rate in man. This is unfortunate because relatively simple adsorption methods for the specific estimation of serum creatinine have been described (24-26).

It is conceivable that unknown factors in the clinical, therapeutic or dietary state of the sub- jects may influence the creatinine clearance. The deviations of the endogenous creatinine clearance from the glomerular filtration rate show so much variability that it would not be surprising to find that this clearance is affected by factors not ordinarily considered in clearance measurements.

Three of the patients included in our study had impaired renal function caused by congestive heart failure. In two of them, the non-specific creatinine clearance fell considerably below the inulin level. The specific creatinine clearances were also unexpectedly low. It seems likely, therefore, that the low endogenous creatinine chromogen clearances found in cardiac failure cannot be attributed to the presence of an unusually large quantity of non-creatinine chromogen in serum. The two patients who showed the low creatinine/inulin clearance ratios had very low urine flows (see Table I). Our data are too limited to permit any conclusions about the importance of this factor.

\section{CONCLUSIONS}

In patients with organic and functional disease of the kidney, the endogenous creatinine clearance is not a satisfactory measure of the glomerular filtration rate. This discrepancy between the creatinine and inulin clearances occurs with both the creatinine-chromogen clearance advocated by Brod and Sirota, and the specific creatinine clearance, determined by the enzymatic method of Miller and Dubos.

It is concluded that in patients with renal disease or in cardiac failure, endogenous creatinine clearance should not be employed as a precise measure of the glomerular filtration rate.

\section{ACKNOWLEDGMENT}

The authors received much help from Doctor Allan M. Butler during this study, and we express our gratitude to him.

\section{REFERENCES}

1. Rehberg, P. B., Studies on kidney function. I. The rate of filtration and reabsorption in the human kidney. Biochem. J., 1926, 20, 447.

2. Smith, H. W., The Kidney: Structure and Function in Health and Disease. Oxford Univ. Press, New York, 1951.

3. Van Slyke, D. D., Hiller, A., and Miller, B. F., The clearance, extraction percentage and estimated filtration of sodium ferrocyanide in the mammalian 
kidney. Comparison with inulin, creatinine and urea. Am. J. Physiol., 1935, 113, 611.

4. Shannon, J. A., The renal excretion of creatinine in man. J. Clin. Invest., 1935, 14, 403.

5. Miller, B. F., and Winkler, A. W., The renal excretion of endogenous creatinine in man. Comparison with exogenous creatinine and inulin. J. Clin. Invest., 1938, 17, 31.

6. Miller, B. F., Alving, A. S., and Rubin, J., The renal excretion of inulin at low plasma concentrations of this compound, and its relationship to the glomerular filtration rate in normal, nephritic and hypertensive individuals. J. Clin. Invest., 1940, 19, 89.

7. Miller, B. F., and Winkler, A. W., The ferrocyanide clearance in man. J. Clin. Invest., 1936, 15, 489.

8. Miller, B. F., and Dubos, R. J., Studies on the presence of creatinine in human blood. J. Biol. Chem., 1937, 121, 447.

9. Dubos, R. J., and Miller, B. F., The production of bacterial enzymes capable of decomposing creatinine. J. Biol. Chem., 1937, 121, 429.

10. Taggart, J. V., Alving, A. S., and Miller, B. F., Unpublished results.

11. Taggart, J. V., Tubular transport mechanisms. Am. J. Med., 1950, 9, 678.

12. Brod, J., and Sirota, J. H., The renal clearance of endogenous "creatinine" in man. J. Clin. Invest., 1948, 27, 645.

13. Miller, B. F., Leaf, A., Mamby, A. R., and Miller, Z., A comparison of the allantoin and inulin clearances for the measurement of filtration rate in the diseased human kidney. J. Clin. Invest., 1952, 31, 314.

14. Goldring, W., and Chasis, H., Hypertension and Hypertensive Disease. The Commonwealth Fund, New York, 1944.

15. Rolf, D., Surtshin, A., and White, H. L., A modified diphenylamine procedure for fructose or inulin de- termination. Proc, Soc. Exper. Biol. \& Med., 1949, 72, 351.

16. Alving, A. S., Rubin, J., and Miller, B. F., A direct colorimetric method for the determination of inulin in blood and urine. J. Biol. Chem., 1939, 127, 609.

17. Fujita, A., and Iwatake, D., Bestimmung des echten Blutzuckers ohne Hefe. Biochem. Ztschr., 1931, $242,43$.

18. Bonsnes, R. W., and Taussky, H. H., On the colorimetric determination of creatinine by the Jaffe reaction. J. Biol. Chem., 1945, 158, 581.

19. Miller, B. F., Allinson, M. J. C., and Baker, Z., Studies on the metabolism of creatine and creatinine. I. Specific enzymatic methods for the analysis of creatine and creatinine in tissues. J. Biol. Chem., 1939, $130,383$.

20. Baldwin, D. S., Sirota, J. H., and Villarreal, H., Diurnal variations of renal function in congestive heart failure. Proc. Soc. Exper. Biol. \& Med., 1950, 74, 578.

21. Brod, J., Případ maligni hypertense s chronickou pyelonefritidou. Časop. lék. česk., 1948, 87, 1141.

22. Brod, J., and Kotátko, J., Vliv caronamidu na tubulární sekreci v ledvinách. Časop. lék. česk., 1949, 88, 549.

23. Hare, K., Goldstein, H., Barnett, H. L., McNamara, H., and Hare, R. S., Renal excretion of creatinine in man. Federation Proc., 1949, 8, 67.

24. Borsook, H., Micromethods for determination of ammonia, urea, total nitrogen, uric acid, creatinine (and creatine), and allantoin. J. Biol. Chem., 1935, $110,481$.

25. Hare, R. S., Endogenous creatinine in serum and urine. Proc. Soc. Exper. Biol. \& Med., 1950, 74, 148.

26. Miller, Z., and Miller, B. F., Specific determination of serum creatinine. Proc. Soc. Exper. Biol. \& Med., 1951, 78, 471. 